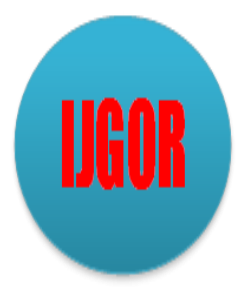

\title{
Estimation of the Amount of Rice Crop Insurance Premium in the Citarum River Basin
}

\author{
Nurfadhlina Abdul Halim ${ }^{\text {a }}$, Muhammad Faiz Rifqi ${ }^{\text {b }}$, Endang Soeryana Hasbullah ${ }^{\mathrm{c}}{ }^{*}$ \\ ${ }^{\mathrm{a}}$ Faculty of Science and Technology, Universiti Sains Islam Malaysia, MALAYSIA \\ ${ }^{b, c}$ Department of Mathematics, Faculty of Mathematics and Natural Sciences, Universitas Padjadjaran, \\ INDONESIA
}

*Corresponding Author: endang.soeryana@unpad.ac.id

\begin{abstract}
Determination of crop insurance premiums in the Citarum River basin can be calculated by mathematical methods. One of the methods of calculation of the premium that is the normal curve methods with data on crop productivity is assumed to be Gaussian. In this thesis are discussed in crop insurance premium calculations Areas Citarum River basin West Bandung Regency with normal curve method with a significant level of coverage. These methods are used because data on crop productivity gained Gaussian. Normal curve method is used without using the assumption of coefficients of variation, and try for some level of coverage. Application materials used are rice crop productivity data in the Citarum River basin of West Bandung Regency in 2008-2014. This research resulted in the value of the rice crop insurance premiums for farmers in the area based on a certain level of coverage.
\end{abstract}

Keywords: Crop Insurance, Premiums, the Normal Curve Method, The Level Of Coverage

\section{Introduction}

The agricultural sector is one sector that has an important role in the national economy (Segura, 2010; Tindeche, 2014). Including the agricultural sector in the Citarum River Basin. One of the roles of the agricultural sector is as a foreign exchange earner when agricultural products are exported abroad (Josling, 2010; Glauber, 2012; Rome, 2018; Haberli, 2018). However, on the other hand the agricultural sector has a high risk of natural dynamics or pest attacks that can result in a decrease in production yields and so far the farmers bear the risks themselves. On the other hand, the level of welfare of farmers so far tends to be below the poverty line. Farmer's family income is estimated to be around IDR 500 thousand per month so that the problem of farmer's poverty becomes a crucial problem (Druilhe, 2012; FAO, 2017). In the face of risk, farmers have done various things to minimize losses. However, the ability of farmers to deal with these risks is often constrained by lack of capital. 
The agricultural sector is one sector that has an important role in the national economy (Segura, 2010; Tindeche, 2014). Including the agricultural sector in the Citarum River Basin. One of the roles of the agricultural sector is as a foreign exchange earner when agricultural products are exported abroad (Josling, 2010; Glauber, 2012; Rome, 2018; Haberli, 2018). However, on the other hand the agricultural sector has a high risk of natural dynamics or pest attacks that can result in a decrease in production yields and so far the farmers bear the risks themselves. On the other hand, the level of welfare of farmers so far tends to be below the poverty line. Farmer's family income is estimated to be around IDR 500 thousand per month so that the problem of farmer's poverty becomes a crucial problem (Druilhe, 2012; FAO, 2017). In the face of risk, farmers have done various things to minimize losses. However, the ability of farmers to deal with these risks is often constrained by lack of capital.

During this time the government has issued many policies and programs to help farmers face these risks. Some of them are such as seed subsidies, fertilizer subsidies, production input assistance, and credit to the agricultural sector. However, this assistance is still not enough to overcome various problems in the agricultural sector, especially problems caused by natural conditions. Thus, one effort that needs to be done to reduce the risk of loss is to introduce crop insurance in the agricultural sector. This strategy has been widely adopted by farmers in developed countries, or some farmers in developing countries (Surminski, 2013; Surminski, 2014) to avoid losses. Therefore, agricultural insurance is one strategy to deal with the risks of damage in the agricultural sector. Including for the agricultural sector in the Citarum watershed.

\section{Materials and Methods}

This research will discuss the calculation of crop insurance premiums (rice) using the normal curve method and the calculation of reserve values using the Unearned Premium Reserve (UPR) method. The normal curve method itself is a method for calculating agricultural insurance premiums using the help of a normal distribution curve. This method was first discovered by Ralph R. Botts and James N. Boles in 1958, which was then used by the Federal Crop Insurance Corporation (FCIC) as a method for determining crop insurance premiums in the United States, and Manitoba Crop Insurance (MCIC) in Canada. This method is used because the frequency of distribution of rice productivity in the Citarum River Basin (DAS) is normally distributed. This method assumes that the parameter value of the variance coefficient is 0.25 or in other words the parameter value of the standard deviation of agricultural products is $25 \%$ of the average parameter value. While Unearne Premium Reserve is a calculation of the value of premium reserves that have not yet been income.

\subsection{The Normal Curve Method}

In the normal curve method with coverage level $C(0<C<1)$, Y rice productivity is normally distributed with an average $\mu$ and variance $\sigma^{2}$. Compensation $I$ for $Y$ yields less than the coverage level $C$ can be written as follows:

$$
I= \begin{cases}C \mu-Y & ; Y \leq C \mu \\ 0 & ; Y \geq C \mu\end{cases}
$$

The above compensation can be calculated as follows:

$$
E(I)=[E(C \mu-Y \mid Y \leq C \mu][P(Y \leq C \mu)]
$$




$$
\begin{aligned}
& =\left[C \mu-\left(\mu-\sigma \frac{\phi\left(\frac{C \mu-\mu}{\sigma}\right)}{\phi\left(\frac{C \mu-\mu}{\sigma}\right)}\right] \mid\left[\phi\left(\frac{C \mu-\mu}{\sigma}\right)\right]\right. \\
& =\left[\phi\left(\frac{C \mu-\mu}{\sigma}\right)\right](C \mu-\mu)+\left[\phi\left(\frac{C \mu-\mu}{\sigma}\right)\right](\sigma)
\end{aligned}
$$

The above equation is a formula used to calculate the premium value of the normal curve method, so it can be written:

$$
\operatorname{PREMIUM}=\left[\phi\left(\frac{C \mu-\mu}{\sigma}\right)\right](C \mu-\mu)+\left[\phi\left(\frac{C \mu-\mu}{\sigma}\right)\right](\sigma)
$$

\subsection{Unearned Premium Reserve (UPR)}

There are several methods used in the calculation of this Unearned Premium Reserve. Which will be used in this thesis is the 1/24 method, where in this method each policy is issued at the beginning of the month and mid-month.

Because in this study using the 1/24 method, the premium value per one planting period per half month will be converted first. One planting season averages about 4 months, then the reserve value is searched using the formula:

$$
U P R=P_{0} \cdot F(t) \cdot(1-k)
$$

with,

$P_{0} \quad$ : Premium value

$F(t) \quad$ : Time period

K : $1 / 24$

\section{Results and Discussion}

\subsection{Rice Crop Insurance Premium in the Citarum River Basin}

The data used in this study are secondary data, namely Rice Crop Productivity Data in the Citarum Watershed, West Bandung Regency from 2010 to 2014, which is attached in Appendix 1. Furthermore, these data will be used to estimate the value of crop insurance premiums in the Citarum Watershed. . Following is a table of rice productivity data in the Citarum River Basin in West Bandung Regency.

Table 1. Rice productivity data in the Citarum watershed from 2010-2014

\begin{tabular}{|c|c|c|c|}
\hline Years & $\begin{array}{c}\text { BROAD HARVEST } \\
(\mathrm{Ha})\end{array}$ & $\begin{array}{c}\text { PRODUCTION } \\
(\text { Ton })\end{array}$ & $\begin{array}{c}\text { PRODUCTIVITY } \\
(\mathrm{Ku} / \mathrm{Ha})\end{array}$ \\
\hline
\end{tabular}




\begin{tabular}{|l|l|l|l|}
\hline 2008 & & 175,646 & 55.48 \\
\hline 2009 & & 214,702 & 59.84 \\
\hline 2010 & 46,915 & 267,348 & 56.99 \\
\hline 2011 & 38,998 & 222,899 & 57.16 \\
\hline 2012 & 39,338 & 230,692 & 58.64 \\
\hline 2013 & 41,631 & 252,712 & 60.70 \\
\hline 2014 & 42,999 & 256,687 & 59.70 \\
\hline
\end{tabular}

Using the IBM SPSS 23 application, testing of data distribution using the Kolmogorov-Smirnov Test One-Sample method obtained results as shown below

Gambar 1 Hasil metode One-Sample Kolmogorov-Smirnov Test

One-Sample Kolmogorov-Smirnov Test

\begin{tabular}{|c|c|c|}
\hline & & VAR00001 \\
\hline $\mathrm{N}$ & & 7 \\
\hline \multirow[t]{2}{*}{ Normal Parameters ${ }^{a, b}$} & Mean & 5.9649 \\
\hline & Std. Deviation & .20016 \\
\hline \multirow[t]{3}{*}{ Most Extreme Differences } & Absolute & .294 \\
\hline & Positive & .164 \\
\hline & Negative & -.294 \\
\hline Test Statistic & & .294 \\
\hline Asymp. Sig. (2-tailed) & & $.068^{\circ}$ \\
\hline
\end{tabular}
a. Test distribution is Normal.
b. Calculated from data.
c. Lilliefors Significance Correction.

Figure 1. Results of the Kolmogorov-Smirnov Test One-Sample method

In the above results it can be seen that the value of sig $=0.068>0.05$, so that Ho is not rejected or accepted, which means that the productivity data of rice plants in the Citarum watershed are normally distributed.

This study involved some adjustments related to the compensation system and coverage level involvement. In this case farmers who only harvest a maximum of $25 \%$ of the planted area will receive full compensation of IDR $6,000,000.00$ As for other cases depending on the level of damage and age of planting. 


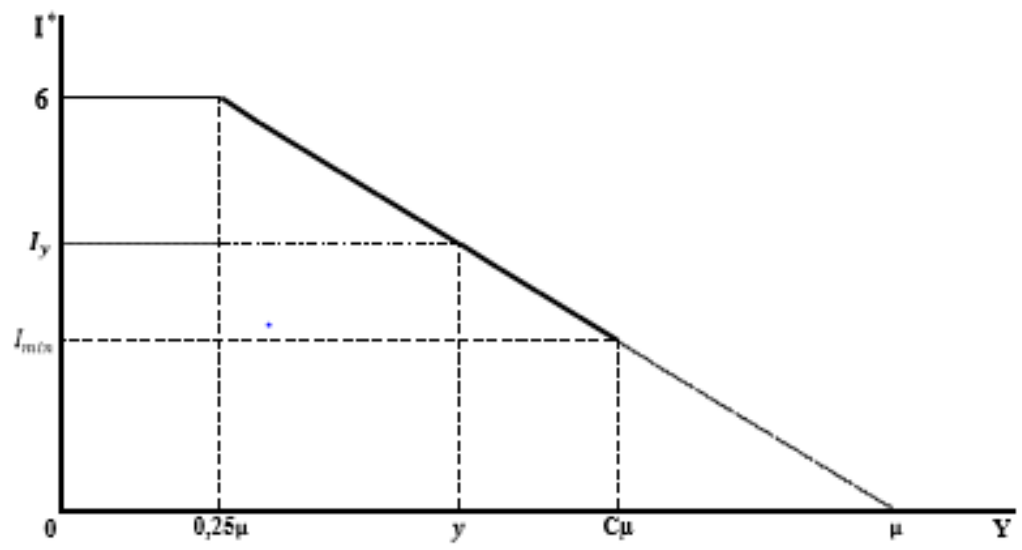

Figure 2. Compensation system with adjustments

So that compensation for farmers can be modeled as follows:

$$
I^{*}= \begin{cases}6 & ; Y \leq 0.25 \mu \\ \frac{8}{\mu}(\mu-Y) & ; 0.25<Y \leq C \mu \\ 0 & ; Y>C \mu\end{cases}
$$

The next step is to look for expectations of compensation in Eq. Yield or rice productivity is equal to Y, normally distributed with the average $\mu$ variance $\sigma^{2}$, then the compensation expectations can be calculated as follows:

$$
\begin{gathered}
E(I)=E\left(\frac{8}{\mu}(\mu-Y) \mid 0.25 \mu<Y<C \mu\right) P(0.25 \mu<Y \leq C \mu) \\
E(I)=\frac{8}{\mu}\left[\mu-\left(\mu+\sigma \frac{\left.\phi\left(\frac{0.25 \mu-\mu}{\sigma}\right)-\phi\left(\frac{C \mu-\mu}{\sigma}\right)\right)}{\phi\left(\frac{C \mu-\mu}{\sigma}\right)-\phi\left(\frac{0.25 \mu-\mu}{\sigma}\right)}\right)\right]\left[\phi\left(\frac{C \mu-\mu}{\sigma}\right)-\phi\left(\frac{0.25 \mu-\mu}{\sigma}\right)\right] \\
\text { Premium }=6 \phi\left(\frac{-0.75 \bar{Y}}{S}\right)+\frac{8 S}{\bar{Y}}\left(\phi\left(\frac{C \bar{Y}-\bar{Y}}{S}\right)-\left(\frac{-0.75 \bar{Y}}{S}\right)\right)
\end{gathered}
$$

With an average of $\boldsymbol{Y}^{-}=\mathbf{5}, 9649$ and standard deviation $\boldsymbol{S}=1.491225$, for coverage rates of 40\%, 50\%, 60\%, $65 \%, 70 \%, 75 \%$. The value of crop insurance premiums in the Citarum River Basin is calculated using equation (2) and the results are as follows; 88,200, 243,800, 551,040, 1,412,400, 1,935,600 are the total premiums. Based on government regulations, $80 \%$ of premiums are borne by the government, so farmers only bear $20 \%$, i.e.; 17,640 , $60,960,137,760,282,480,387,120$.

If a farmer buys an agricultural insurance policy with a $60 \%$ coverage rate, then the farmer only has to pay IDR $137,760.00$ per hectare of land for one growing season. If at the time of harvest later the farmers' rice yields are less than $25 \%$ of the average long-term yield, then the farmer gets full compensation, amounting to IDR 6,000,000. If the yields are between $25 \%$ and $60 \%$ of the average long-term yield, then the farmer receives compensation in the amount adjusted to the farmer's yield. If the farmer's rice yield is more than $60 \%$ of the average long-term yield, 
then the farmer does not get compensation. The same explanation can be applied for coverage levels other than $60 \%$.

\subsection{Reserve Value of Rice Crop Insurance in the Citarum River Basin}

Calculate the reserve value in this thesis using the $1 / 24$ method, based on the formula, where the insurance policy is assumed to be issued every mid-month. Must be converted first value of premiums per one planting period to premiums for policies in this method. Next with the formula:

$$
U P R=P_{0} \cdot F(t) \cdot(1-k)
$$

Looked for the value of reserves based on premiums for each level of coverage. The results are obtained as follows; $91,282,254,450,576,107,1,461,748,2,013,222$ for premiums with coverage rates of 40\%, 50\%, 60\%, $70 \%$ and $75 \%$.

\section{Conclussion}

The value of crop insurance premiums (paddy) in the Citarum River Basin Area of West Bandung Regency, each with a coverage level of $40 \%, 50 \%, 60 \%, 70 \%$ and $75 \%$ are:

1. IDR $88,200.00$ with a premium charged to farmers of IDR $17,640.00$ per one planting period

2. IDR $243,800.00$ with a premium charged to farmers of IDR $60,960.00$ per one planting period

3. IDR $551,040.00$ with a premium charged to farmers amounting to IDR $137,760.00$ per one planting period

4. IDR $1,412,400.00$ with a premium charged to farmers amounting to IDR 282,480.00 per one planting period

5. IDR 1,935,600.00 with a premium charged to farmers amounting to IDR 387,120.00 per one planting period.

The value of reserves for crop insurance (paddy) in the Citarum River Basin in West Bandung Regency with $40 \%, 50 \%, 60 \%, 70 \%$ and $75 \%$ coverage, respectively:

1. IDR $91,282.00$ per one insurance policy issued

2. IDR $254,450.00$ per one insurance policy issued

3. IDR 576,107.00 per one insurance policy issued

4. IDR $1,461,748.00$ per one insurance policy issued

5. IDR 2,013,222.00 per one insurance policy issued

\section{References}

Booth P., Chadburn, R.,Cooper, D., Haberman, S., James, D. 1999. Modern Actuarial Theory and Practice. Chapman \& Hall / CRC

Kaas, R., Goovaerts, M., Dhaene, J., Denuit, M. 2008. Modern Actuarial Risk Theory: Using R. Springer, Berlin / Heidelberg

Tindeche, C., Marcuta, A., Marcuta L. (2014). Importance Of The Agricultural Sector As A Branch Of The

National Economy. Scientific Papers Series Management, Economic Engineering in Agriculture and Rural Development Vol. 14, Issue 4,ISSN 2284-7995, E-ISSN 2285-3952.

Segura, J. A. (2010). The Contribution Of Agriculture To Sustainable Development In Jamaica. The Contribution Of Agriculture To Sustainable Development In Jamaica, Inter-American Institute for Cooperation on Agriculture (IICA). 
Josling, T., Anderson, K., Schmitz, A., \& Tangermann, S. (2010). Understanding International Trade in Agricultural Products: One Hundred Years of Contributions by Agricultural Economists. American Journal of Agricultural Economics, 92(2), 424-446. doi:10.1093/ajae/aaq011

Rome. (2018). The State Of Agriculturalcommodity Markets: Agricultural Trade,Climate Change And Food Security. Food and Agriculture Organization of the United Nations (FAO). ISBN 978-92-5-130565-2

Glauber, J.W. 2012. The Growth of the Federal Crop Insurance Program, 1990-2011. American Journal of Agricultural Economics, 95(2): 482-88

Haberli, C. 2018. Potential Conflicts Between Agricultural Trade Rules and Climate Change Treaty Commitments. SOCO 2018 Background Paper, Rome.

Druilhe, Z. \& Barreiro-Hurlé, J. 2012. Fertilizer subsidies in Sub-Saharan Africa. Agricultural Development Economics Division Working Paper. FAO

FAO. 2017. GIEWS Update Bangladesh: Severe floods in 2017 affected large numbers of people and caused damage to the agriculture sector, . http://www.fao.org/3/a-i7876e.pd

Surminski, S. 2013. The Role of Insurance in Reducing Direct Risk - The Case of Flood Insurance. International Review of Environmental and Resource Economics, 7: 241-278, ISSN 1932-1465;

Surminski, S. 2014. "The Role of Insurance Risk Transfer in Encouraging Climate Investment in Developing Countries.” In Harnessing Foreign Investment to Promote Environmental Protection Incentives and Safeguards. P. M. Dupuy and J. E. Vĩnuales, eds. Cambridge: Cambridge University Press. pp. 228-250.

Born, P., Klein, R. (2015). Best Practices for Regulating Property Insurance Premiums and Managing Natural Catastrophe Risk in the United States. National Association of Mutual Insurance Companies (NAMIC) 